\title{
Jino Chinese
}

National Cancer Institute

\section{Source}

National Cancer Institute. lino Chinese. NCI Thesaurus. Code C158201.

A Chinese person from the Jino ethnic group. 